\title{
Using the IUCN Red List to determine effective conservation strategies
}

\author{
Matt W. Hayward
}

Received: 9 February 2011/Accepted: 15 June 2011/Published online: 29 June 2011

(C) The Author(s) 2011. This article is published with open access at Springerlink.com

\begin{abstract}
Threatened species lists continue to grow while the world's governments fail to meet biodiversity conservation goals. Clearly, we are failing in our attempts to conserve biodiversity. Yet 37 mammal species genuinely improved in status in the 2009 IUCN Red List, suggesting there are ways to successfully conserve biodiversity. Here, I compare the threats and conservation actions (proposed and implemented) by the expert assessors of the Red List of improving species to a further 144 declining mammal species to determine whether specific threats were more easily remedied, and whether certain conservation actions were more successful than others. Declining species were faced with different threatening processes to mammals improving in status suggesting some threats were easier to treat (e.g. hunting) than others (climate change, invasive species). Declining species had different proposed and implemented conservation actions than improving species suggesting some actions are more successful than others. Threatened species were invariably found in conservation areas, suggesting protected area creation alone is not an overly successful strategy for species at risk of extinction. Conservation actions were more frequently implemented for improving than declining species suggesting active conservation is effective in improving the status of biodiversity. There were significant differences between proposed and implemented conservation actions suggesting some actions are easier to implement than others. Reintroduction, captive breeding and hunting restriction were more effective in conserving mammals than site creation and invasive species
\end{abstract}

\footnotetext{
M. W. Hayward ( $₫)$

Australian Wildlife Conservancy, PO Box 432, Nichol's Point, VIC 3501, Australia e-mail: hayers111@aol.com
}

M. W. Hayward

School of Biological, Earth and Environmental Science, University of New South Wales, Sydney, NSW 2056, Australia

M. W. Hayward

Animal and Wildlife Sciences, University of Pretoria, Pretoria 0001, South Africa

M. W. Hayward

Centre for African Conservation Ecology, Nelson Mandela Metropolitan University, Port Elizabeth 6013, South Africa 
control. These findings highlight effective conservation actions for mammals worldwide and allow the rationalisation of threat mitigation measures to ensure economically justifiable biodiversity conservation strategies.

Keywords Conservation management - Status - Threat abatement - IUCN Red List · Protected area creation - Reintroduction - Captive breeding · Hunting · Conservation planning

\section{Introduction}

Effective conservation requires the separation of biodiversity from the factors threatening it (Hayward 2009a). Achieving this has resulted in well known conservation successes, including the Californian condor Gymnogyps californianus, which has increased from 6 to 130 wild individuals following the cessation of persecution, a reduction in lead poisoning and captive breeding (BirdLife International 2009). Similarly, the little kiwi Apteryx owenii, was upgraded from vulnerable to near threatened following successful reintroductions to predator-free islands (Birdlife International 2008), while the greater stick-nest rat Leporillus conditor improved from endangered to vulnerable through the creation of new populations via reintroduction to sites free of introduced predators (Morris and Copley 2008). Despite these rare successes, biodiversity is becoming increasingly threatened with extinction (Schipper et al. 2008) and we are failing in our efforts to conserve species (Butchart et al. 2010).

The IUCN Red List of threatened species is the most comprehensive dataset of the conservation status, trends and threats of the Earth's biodiversity (Hoffmann et al. 2008; Rodrigues et al. 2006; Schipper et al. 2008). In the 2009 IUCN Red List assessment, 181 mammal species were considered to have genuinely changed status since the previous assessment (IUCN 2009; Vie et al. 2009). These changes in status were not attributed to recent improvements in our knowledge of the natural history of the species, but rather to actual alterations in their abundance or distribution (Vie et al. 2009). The Red List provides assessments by the world's leading experts on each species, as well as a description of the processes threatening each species. The Red List expert assessors then document the conservation actions that have been undertaken for each species, and propose further actions they consider would improve the status of each species based on their expert knowledge, discussion with other experts and literature reviews. Although there is scope for improvement (Findlay et al. 2009; Hayward 2009b), the Red List affords the opportunity to assess the value of various conservation management actions.

In this study, I aimed to assess whether mammal species that improved in status had specific threats associated with them compared to declining species. I then aimed to determine whether there was congruence between these threats and the proposed conservation management actions. Finally, I aimed to determine which existing conservation management actions were successful in improving the conservation status of mammals. The rationale behind these aims is that conservation threats must be separated from the species we aim to conserve in order to yield successful conservation outcomes (Hayward and Kerley 2009). Consequently, I predicted that there would be differences in the types of factors threatening declining species compared to improving species because some threats are easier to manage (e.g., persecution by humans compared to climate change). I also predicted that some conservation actions would be more successful in achieving conservation success than others. 


\section{Materials and methods}

I reviewed the 2009 IUCN Red List (2009) and studied the mammal species that exhibited genuine improvements or declines in status since the previous global mammal assessment (Vie et al. 2009). That is, well monitored species that changed status based on changes in abundance or distribution rather than based on an increased amount of information. For each species, I recorded the threatening processes affecting them, the conservation actions that were proposed by the species' experts in the Red List assessments (proposed) and the conservation actions reported to have been undertaken on these species already (implemented). I attempted to use appropriate and common terminology relating to the IUCN assessments and the Red List throughout (Salafsky et al. 2008).

I used $\chi^{2}$ tests to assess the difference between the frequency of threats, and the proposed and actual conservation actions for declining and improving species. I used Pearson's correlations to assess whether specific threats were correlated with specific proposed or actual conservation actions. Finally, I ran generalised linear models (GLM) with binomial distributions and logit link functions to assess which conservation actions were most successful in improving the conservation status of mammals. The dependent variable of the GLM was improving (1) and declining (0) mammal species, while I used five predictive variables following the recommendations of Harrell (2001). I restricted the predictive variables to active conservation strategies: protected area creation, reintroductions, captive breeding, hunting restrictions and invasive species control because these formed greater than $75 \%$ of conservation actions. Models with a $\Delta \mathrm{AIC}_{\mathrm{c}}$ of $<2$ were considered as showing substantial support, whereas those with $\Delta \mathrm{AIC}_{\mathrm{c}}>7$ showed no support (Burnham and Anderson 2001). Models with $\Delta \mathrm{AIC}_{\mathrm{c}}<2$, but with additional parameters to other strongly supported models were not considered the best fit for the data because the penalty for additional parameters with AIC is 2 , but model deviance is not reduced an amount sufficient to overcome this (i.e., the uninformative parameter does not explain enough variation to justify its inclusion in the model and so has little ecological effect; Arnold 2010). I used Akaike's (1973, 1974) weights to determine the percentage likelihood that a model represents the best fit for the data. I used multimodel averaging $(\theta)$ to determine the variable most influencing the change in species' status (Burnham and Anderson 1998).

\section{Results}

One-hundred and eighty-one species exhibited genuine improvements or declines in status in the 2009 IUCN Red List. Thirty-seven (37) of these improved and 144 declined. Eightytwo $(82.6 \pm 2.8 \%)$ percent of improving species and $91.8 \pm 2.1 \%$ of declining species occurred in protected areas.

There was a significant difference between the threats that affect species that improved in status compared to those that decreased $\left(\chi^{2}=428.9\right.$, df $\left.=9, P<0.001\right)$ with proportionally more improving species threatened by agricultural development and biological resource use (hunting) (Fig. 1). Conversely, proportionally more declining species were threatened by transportation corridors, human intrusions, invasive species, pollution and climate change (Fig. 1).

Site management, protected area creation and harvest restriction were the most frequently proposed conservation actions for threatened mammals (Fig. 2a). Species that improved in status had more conservation actions proposed for them, and there was a 


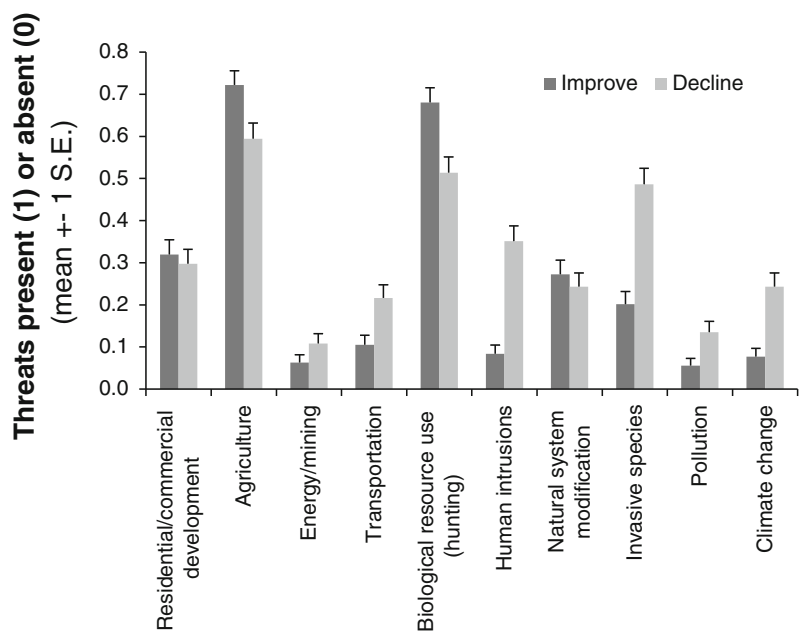

Fig. 1 Proportion of threatening processes affecting declining and improving mammals

significant difference between the proposed conservation measures for improving and declining species $\left(\chi^{2}=282.3\right.$, $\left.\mathrm{df}=11, P<0.001\right)$ with restoration and reintroduction relatively more frequently recommended for improving species, while protected area creation and management were most frequently proposed for both (Fig. 2a).

Conservation actions were more frequently implemented for improving than declining species $\left(\chi^{2}=83.1\right.$, df $=6, P<0.001$ ) (Fig. 2b). Hunting restriction (33\%), research $(20 \%)$, protected area creation (19\%) and reintroductions (16\%) were most frequently implemented for conserving threatened mammals (Fig. 2b).

Proposed conservation actions for species threatened by residential/commercial developments were correlated with hunting restrictions $(R=0.19, n=184, P<0.05$ for all) and livelihood/economic incentives $(R=0.26)$, whereas those species threatened by agricultural development had protected area creation $(R=0.23)$ and site management $(R=0.22)$ proposed. Species threatened by energy and mining developments had restoration $(R=0.16)$ and livelihood/economic incentives proposed $(R=0.21)$. For the majority of threats however, there was no correspondence with conservation actions.

There was a significant difference between proposed and implemented conservation actions $\left(\chi^{2}=127.19\right.$, df $=11, P<0.001$; Fig. 3). Site management, harvest management, training and livelihood/economic incentives were frequently proposed but never implemented, while invasive species control, captive breeding and hunting restrictions were more frequently implemented than proposed (Fig. 3).

One GLM exhibited substantial support (Model 2), with species improving in status because of reintroductions, captive breeding, and hunting restriction (Table 1). Model 1 included these variables as well as an additional one (protected area creation) however this was excluded because the additional parameter did not improve the model deviance sufficiently (following Arnold 2010). The Akaike's weights for these two models sum to 0.66 suggesting there was a $66 \%$ likelihood that these models are the best fit for the data (Table 1). Reintroduction $(\theta=99.9)$, captive breeding (98.5) and hunting restriction (92.0) had model averages almost double that of site creation (57.2) and over three times greater than invasive species control (27.6). This means that reintroductions, captive 

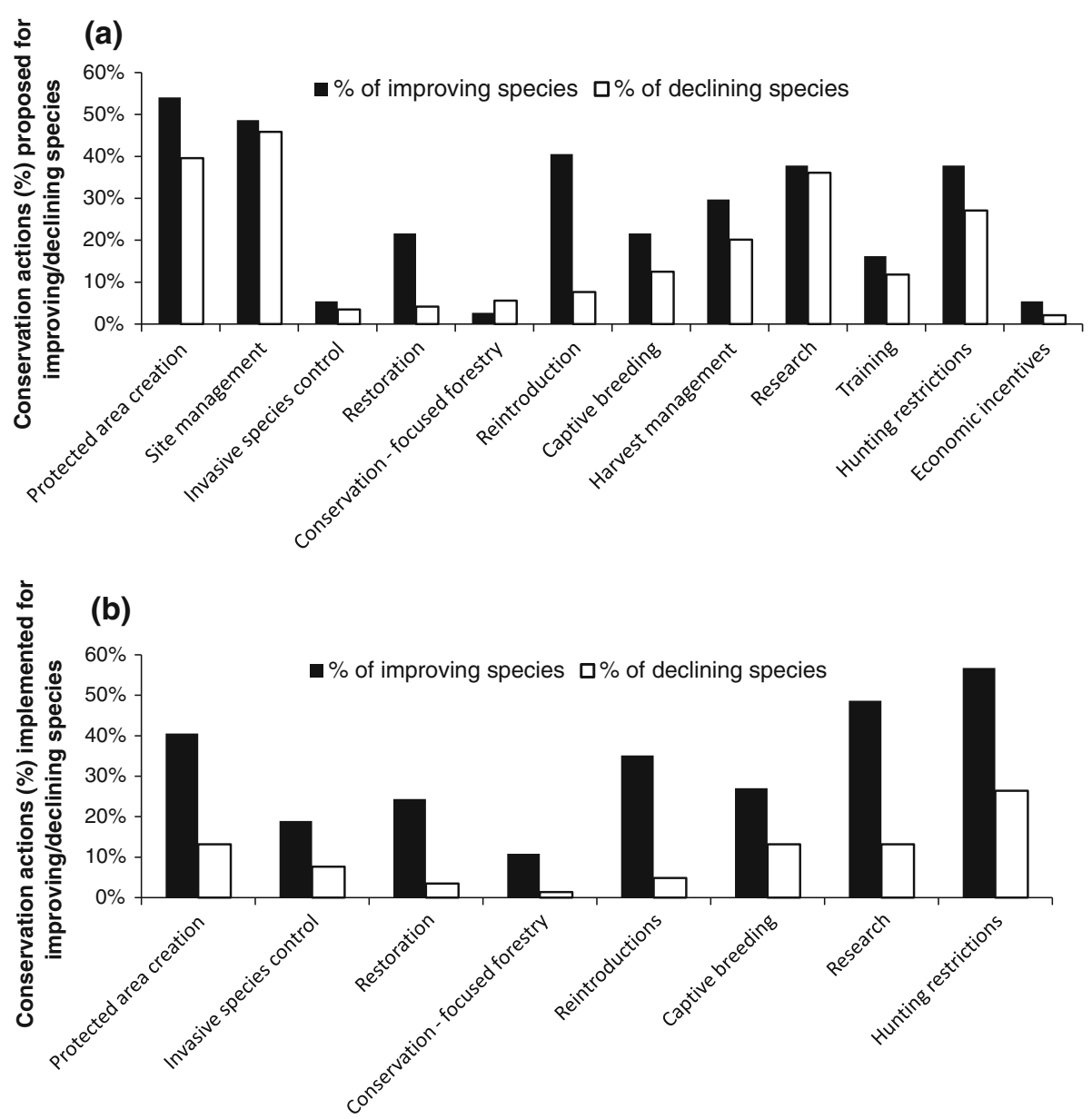

Fig. 2 Proportion of a proposed and $\mathbf{b}$ implemented conservation actions for declining and improving species based on the 2009 IUCN Red List

breeding and hunting restrictions are almost twice as successful conservation actions for mammals than site creation and three times more successful as invasive species control.

\section{Discussion}

Despite the best efforts of conservation managers, we are failing to adequately conserve biodiversity (Butchart et al. 2010). New innovations are urgently required to address this (Possingham 2010) and appropriate treatment of threats is critical to rationalise the existing 'scatter-gun' approach to threat amelioration (Hayward 2009b). The results of this paper highlight effective and ineffective methods of improving the status of the world's biodiversity.

Declining species are threatened by different factors (transportation corridors, human intrusions, invasive species, pollution and climate change) than improving species (agricultural development and biological resource use (hunting); Fig. 1). While acknowledging 


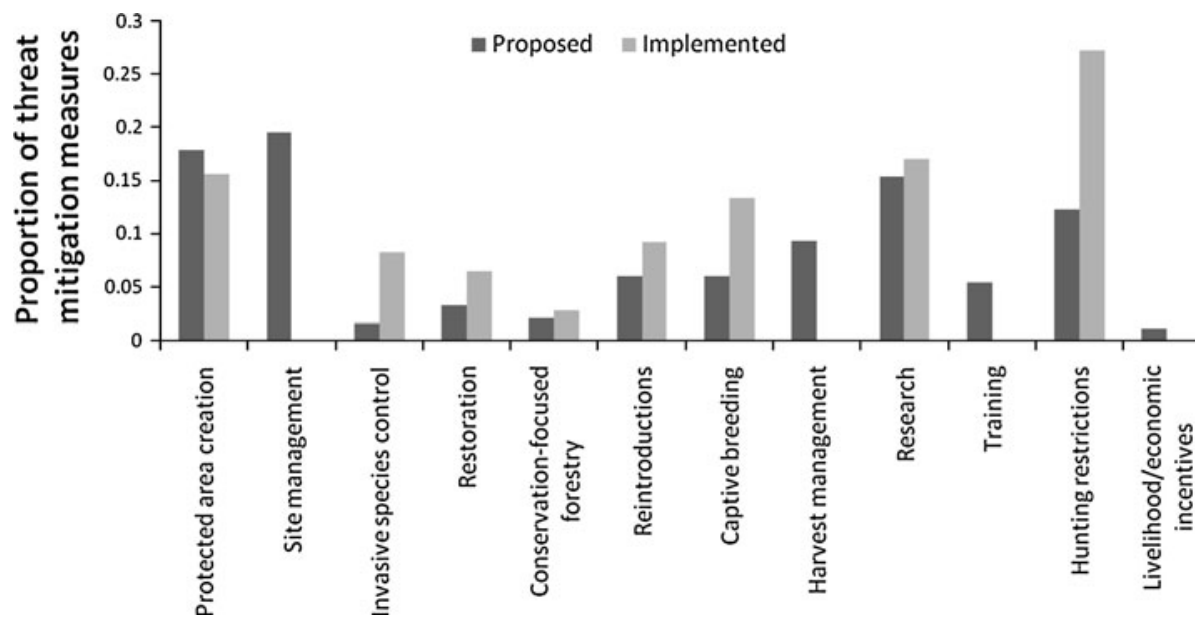

Fig. 3 The proportion of conservation actions proposed and implemented for mammals based on the 2009 IUCN Red List

that this is a broad-scale study and conservation actions are case specific, this disparity may imply that some threats are more easily treated than others. For example, effective legislation and policy can overcome the impacts of over-hunting, whereas threats like invasive species, pollution and climate change are less effectively defended and at much greater financial cost.

Figure 2 highlights two important issues. Firstly, invariably several conservation actions are proposed for threatened species suggesting conservation managers may not know the critical factor(s) threatening each species, although this may reflect the synergistic effects of multiple threats (Brook et al. 2008). This is largely due to our lack of knowledge on these threatened species. Secondly, the disparity between the percentage of actions implemented on declining and improving species (Fig. 2b) suggests that active conservation strategies may be successful in improving the status of threatened species. Furthermore, some conservation actions appear more successful than others (Table 1). Assessments of bird conservation using the Red List data suggests conservation actions have averted $20 \%$ of the extinctions that would otherwise have occurred over the last century (Brooks et al. 2009). The data presented in this paper suggest that direct, intensive conservation actions may be similarly beneficial to mammals. Furthermore, some actions, particularly those requiring intensive management (e.g. the more derived conservation actions like reintroductions, captive breeding and hunting restrictions), appear to be more successful than others (e.g. protected area creation, invasive species control).

This analysis also illustrates some critical elements of mammalian conservation. Firstly, threatened mammals are almost invariably located within protected areas (and yet remain threatened) and in contrast to threatened birds (Beresford et al. 2010), suggesting that more than just site protection is needed to ameliorate the majority of threatening processes. This was supported by the generalised model (Table 1) and supports the conclusions of Short and Smith (1994) that protected area creation is a necessary but insufficient step in conserving Australian biodiversity. Nevertheless, the ineffectuality of protected areas alone as a conservation strategy has rarely been recognised by conservation practitioners, with most threatened mammals still having protected area creation proposed as a key threat abatement strategy (Fig. 2a). This is because most IUCN protected area categories primarily 


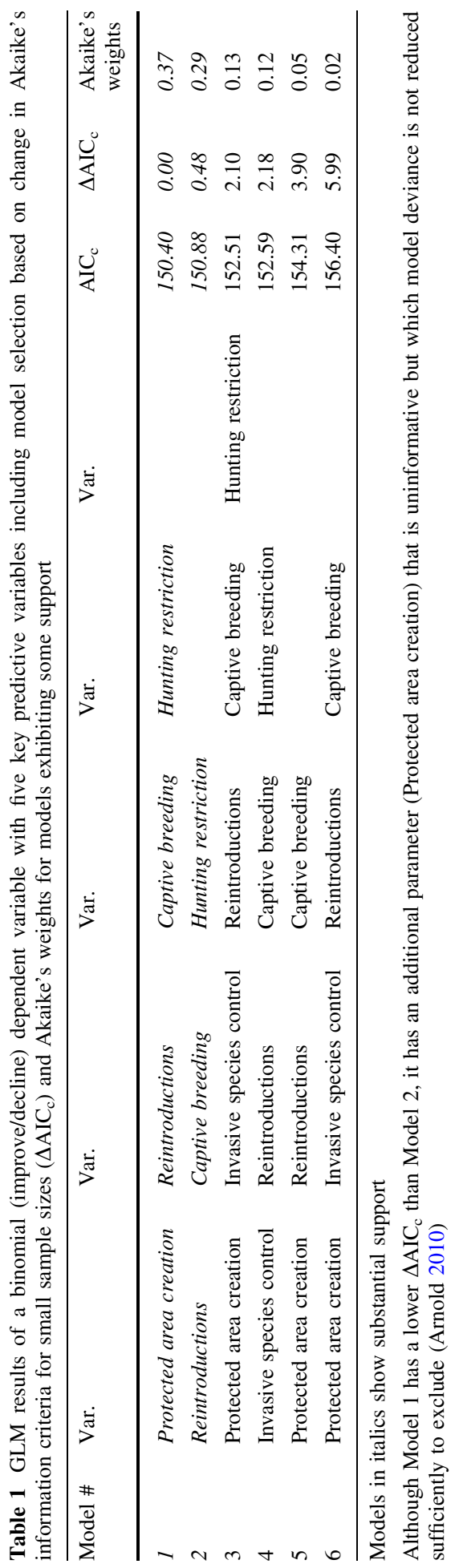


protect against habitat loss (and their effectiveness is overstated; Joppa and Pfaff 2011), whereas extant biodiversity has persisted to date in the remnant habitat patches still present (but see Sang et al. 2010; Tilman et al. 1994). In these protected areas, other threatening processes are far more influential in driving extant mammals toward extinction and this is probably exacerbated by the fact that protected areas are often isolated islands of natural habitat in a matrix of disturbed land (Maiorano et al. 2008). Even very large protected areas conserve proportionally less biodiversity than their size predicts (Cantu-Salazar and Gaston 2010). Despite a plethora of conservation plans to create adequate and representative protected areas, this does not appear to have benefited threatened mammals. This may be simply because protected areas are satisfactory for common species and may save them from declining into threatened status. Site creation is rarely a solitary solution as there are few unaltered sites remaining for inclusion into the protected area network. While conservation planning is one of the most frequently published topics in conservation journals, conservation plans rarely identify disturbed habitats as priorities for inclusion as conservation estate. These sites need restoration to recreate the original habitats and then probably reintroduction to restore locally extinct species. While creating protected areas has been successful in slowing deforestation in the tropics (Brooks et al. 2009) and reducing the extinction risk of large Indian mammals (Karanth et al. 2010), it is not sufficient to protect tree species richness in tropical forests because they are insufficiently protected from encroaching humans (Fandohan et al. 2011; Pare et al. 2009); that is, they are essentially lines on maps. Similarly, the majority of threatened mammals worldwide tend to be threatened by more than just habitat clearance and so more derived/intensive conservation actions are needed to improve their status.

Secondly, some threatening processes (such as agriculture and hunting) appear more easily treated to allow species to improve in status compared to transportation corridors, human intrusions, invasive species, pollution and climate change (Fig. 1). The former two threats can be treated by site creation in association with restoration and reintroduction, and legislation and effective site management, although the difficulties in controlling bushmeat hunting (Bowen-Jones and Pendry 1999; Milner-Gulland et al. 2003) illustrate it is not a guaranteed conservation strategy. The fragmentation caused by transportation corridors, the wars and unrest associated with human intrusions, the devastation caused by invasive species and climate change are far more chronic threats that require more broadscale and costly conservation actions.

The GLM showed that reintroduction, in conjunction with captive breeding and hunting restriction, was critical to successfully improve the conservation status of mammals. The lack of success of reintroductions alone as a conservation strategy illustrates the importance of removing the agent of the initial decline of the species before conducting the reintroduction (Caughley and Gunn 1996). For example, reintroductions of macropods in Australia invariably fail unless invasive predators are controlled (Short et al. 1992), whereas large predator reintroductions in South Africa have succeeded because the risk of retributive human persecution has been removed through fencing (Hayward et al. 2007). Similarly, 41 tropical forest species now only survive in captivity (Brooks et al. 2009) suggesting species management (captive breeding) has been successful in averting their extinction. In concert with other secondary conservation actions (threat amelioration activities), like hunting control and captive breeding, reintroduction becomes a successful strategy provided the initial agent of decline has been removed (Table 1).

It is likely that there are interactions between the terms used in the model (e.g., invasive species control is invariably required in Australia prior to reintroductions; Finlayson et al. 2008). Invasive species control may reduce threats, but the results from this study suggest 
threatened species are unable to naturally reinvade sites where invasive species control has occurred, leading to a requirement for reintroduction to occur in association with invasive species control. Unfortunately, I was limited by Harrell's (2001) 'rule of thumb' in the number of parameters I could use in the generalised linear modelling. Consequently, I used the modelling to test which were the most successful individual conservation actions rather than looking at the interactions between them.

Finally, social conservation actions, such as policy mechanisms, education, research, conservation incentives and capacity building are all theoretically important for biodiversity conservation, but their effectiveness is poorly known (Brooks et al. 2009). Data deficiency is the bane of the IUCN Red Listing process and a blight on conservation biologists and consequently research is urgently needed to assess the effectiveness of the full gamut of conservation actions to ensure limited conservation funding is not wasted by using inappropriate or ineffective methods. Nonetheless, the findings here illustrate that conservation actions are worthwhile endeavours to improve the status of the world's mammals, and certain actions are more successful than others.

Acknowledgments This manuscript has been improved by the reviews of two anonymous referees.

Open Access This article is distributed under the terms of the Creative Commons Attribution Noncommercial License which permits any noncommercial use, distribution, and reproduction in any medium, provided the original author(s) and source are credited.

\section{References}

Akaike H (1973) Information theory and an extension of the maximum likelihood principle. In: Petrov N, Csadki F (eds) Proceedings of the second international symposium on information theory. Akademiai Kiado, Budapest, pp 267-281

Akaike H (1974) A new look at the statistical model identification. IEEE Trans Auto Control AC 19:716-723

Arnold TW (2010) Uninformative parameters and model selection using Akaike's Information Criterion. J Wildl Manag 74:1175-1178

Beresford AE, Buchanan GM, Donald PF, Butchart SHM, Fishpool LDC, Rondinini C (2010) Poor overlap between the distribution of Protected Areas and globally threatened birds in Africa. Anim Conserv 14:99-214

Birdlife International (2008) Apteryx owenii. In: IUCN Red List of Threatened Species Version 2010.1 www.iucnredlist.org

BirdLife International (2009) Gymnogyps californianus. In: IUCN Red List of Threatened Species. IUCN, Gland

Bowen-Jones E, Pendry S (1999) The threat to primates and other mammals from the bushmeat trade in Africa, and how this threat could be diminished. Oryx 33:233-246

Brook BW, Sodhi NS, Bradshaw CJA (2008) Synergies among extinction drivers under global change. Trends Res Ecol Evol 967:453-460

Brooks TM, Wright SJ, Sheil D (2009) Evaluating the success of conservation actions in safeguarding tropical forest biodiversity. Conserv Biol 23:1448-1457

Burnham KP, Anderson DR (1998) Model selection and multimodel inference: a practical informationtheoretic approach. Springer, New York

Burnham KP, Anderson DJ (2001) Kullback-Leibler information as a basis for strong inference in ecological studies. Wildl Res 28:111-119

Butchart SHM, Walpole MJ, Collen B, van Strien A, Scharlemann JPW, Almond REA, Baillie JEM, Bomhard B, Brown CJ, Bruno J, Carpenter KE, Carr GM, Chanson J, Chenery AM, Csirke J, Davidson NC, Dentener F, Foster M, Galli A, Galloway JN, Genovesi P, Gregory RD, Hockings M, Kapos V, Lamarque J-F, Leverington F, Loh J, McGeoch MA, McRae L, Minasyan A, Hernandez Morcillo M, Oldfield TEE, Pauly D, Quader S, Revenga C, Sauer JR, Skolnik B, Spear D, Stanwell-Smith D, Stuart 
SN, Symes A, Tierney M, Tyrrell TD, Vie J-C, Watson RM (2010) Global biodiversity: indicators of recent declines. Science 328:1164-1168

Cantu-Salazar L, Gaston KJ (2010) Very large protected areas and their contribution to terrestrial biological conservation. Bioscience 60:808-818

Caughley G, Gunn A (1996) Conservation biology in theory and practice. Blackwell Science, Carlton

Fandohan B, Assogbodjo AE, Glele Kakai RL, Sinsin B (2011) Effectiveness of a protected areas network in the conservation of Tamarindus indica (Leguminosea-Caesalpinioiodeae) in Benin. Afr J Ecol 49:40-50

Findlay CS, Elgie S, Giles B, Burr L (2009) Species listing under Canada's Species at Risk Act. Conserv Biol 23:1609-1617

Finlayson GR, Vieira EM, Priddel D, Wheeler R, Bentley JM, Dickman CR (2008) Multi-scale patterns of habitat use by re-introduced mammals: a case study using medium-sized marsupials. Biol Conserv $141: 320-331$

Harrell FE (2001) Regression Modeling Strategies: with applications to linear models, logistic regression and survival analysis. Springer, New York

Hayward MW (2009a) Conservation management for the past, present and future. Biodivers Conserv 18:765-775

Hayward MW (2009b) The need to rationalize and prioritize threatening processes used to determine threat status in the IUCN Red List. Conserv Biol 23:1568-1576. doi:1510.1111/j.1523-1739.2009.01260.x

Hayward MW, Kerley GIH (2009) Fencing for conservation: restriction of evolutionary potential or a riposte to threatening processes? Biol Conserv 142:1-13

Hayward MW, Adendorff J, O'Brien J, Sholto-Douglas A, Bissett C, Moolman LC, Bean P, Fogarty A, Howarth D, Slater R, Kerley GIH (2007) The reintroduction of large carnivores to the Eastern Cape Province, South Africa: an assessment. Oryx 41:205-214

Hoffmann M, Brooks TM, Da Fonseca GAB, Gascon C, Hawkins AFA, James RE, Langhammer P, Mittermeier RA, Pilgrim JD, Rodrigues ASL, Silva JMC (2008) Conservation planning and the IUCN Red List. Endanger Species Res 6:113-125

IUCN (2009) IUCN Red List of Threatened Species. Version 2009.1 www.iucnredlist.org. Accessed 2 June 2009

Joppa LN, Pfaff A (2011) Global protected areas impacts. Proc R Soc Lond (Series B) 278:1633-1638

Karanth KK, Nichols JD, Karanth KU, Hines JE, Christensen NLJ (2010) The shrinking ark: patterns of large mammal extinctions in India. Proc R Soc Lond B 277:1971-1979

Maiorano L, Falcucci A, Boitani L (2008) Size-dependent resistance of protected areas to land-use change. Proc R Soc Lond B 275:1297-1304

Milner-Gulland EJ, Bennett EL, Abernethy KA, Baharr M, Bodmer RE, Brashares JS, Cowlishaw G, Elkan P, Eves H, Fa JE, Peres CA, Roberts C, Robinson J, Rowcliffe JM, Wilkie DS (2003) Wild meat: the bigger picture. Trends Res Ecol Evol 18:351-358

Morris KD, Copley P (2008) Leporillus conditor. In: IUCN Red List of Threatened Species. IUCN, Gland

Pare S, Tigabu M, Savadogo P, Oden PC, Ouadba JM (2009) Does designation of protected areas ensure conservation of tree diversity in the Sudanian dry forest of Burkina Faso? Afr J Ecol 48:347-360

Possingham HP (2010) Is conservation too conservative? Australas Sci 46(April)

Rodrigues ASL, Pilgrim JD, Lamoreux JF, Hoffman M, Brooks TM (2006) The value of the IUCN Red List for conservation. Trends Res Ecol Evol 21:71-76

Salafsky N, Salzer D, Stattersfield AJ, Hilton-Taylor C, Neugarten R, Butchart SHM, Collen B, Cox N, Master LL, O'Connor S, Wilkie DS (2008) A standard lexicon for biodiversity conservation: unified classifications of threats and actions. Conserv Biol 22:897-911

Sang A, Teder T, Helm A, Partel M (2010) Indirect evidence for an extinction debt of grassland butterflies half century after habitat loss. Biol Conserv 143:1405-1413

Schipper J, Chanson JS, Chiozza F, Hoffmann M, Katariya V, Lamoreux J, Rodrigues ASL, Stuart SN, Temple HJ, Boitani L, Lacher TE, Mittermeier RA, Smith AT, Absolon D, Aguiar JM, Amori G, Bakkour N, Baldi R, Berridge RJ, Black PA, Blanc JJ, Brooks TM, Burton JA, Butynski TM, Catullo G, Chapman R, Cokeliss Z, Collen B, Conroy J, Cooke JG, GABd Fonseca, Derocher AE, Dublin HT, Duckworth JW, Emmons L, Emslie RH, Festa-Bianchet M, Foster M, Foster S, Garshelis DL, Gates C, Gimenez-Dixon M, Gonzalez S, Gonzalez-Maya JF, Good TC, Hammerson G, Hammond PS, Happold D, Happold M, Hare J, Harris RB, Hawkins CE, Haywood M, Heaney LR, Hedges S, Helgen KM, Hilton-Taylor C, Hussain SA, Ishii N, Jefferson TA, Jenkins RKB, Johnston CH, Kingdon J, Knox DH, Kovacs KM, Langhammer P, Leus K, Lewison R, Lichtenstein G, Lowry LF, Macavoy Z, Mace GM, Mallon DP, Masi M, McKnight MW, Medellan RA, Medici P, Mills MGL, Moehlman PD, Molur S, Mora A, Nowell K, Oates JF, Olech W, Oliver WRL, Oprea M, Patterson BD, Perrin WF, Polidoro BA, Pollock C, Powel A, Protas Y, Racey P, Ragle J, Ramani P, Rathbun G, Reeves RR, Reilly SB, 
Reynolds JE, Rondinini C, Rosell-Ambal RG, Rulli M, Rylands AB, Savini S, Schank CJ, Sechrest W, Self-Sullivan C, Shoemaker A, Sillero-Zubiri C, Silva ND, Smith DE, Srinivasulu C, Stephenson PJ, Strien Nv, Talukdar BK, Taylor BL, Timmins R, Tirira DG, Tognelli MF, Tsytsulina K, Veiga LM, Via J-C, Williamson EA, Wyatt SA, Xie Y, Young BE (2008) The status of the world's land and marine mammals: diversity, threat and knowledge. Science 322:225-231

Short J, Smith AP (1994) Mammal decline and recovery in Australia. J Mammal 75:288-297

Short J, Bradshaw SD, Giles J, Prince RIT, Wilson GR (1992) Reintroduction of macropods (Marsupialia: Macropodoidea) in Australia-a review. Biol Conserv 62:189-204

Tilman D, May RM, Lehman CL, Nowak MA (1994) Habitat destruction and the extinction debt. Nature 371:65-66

Vie J-C, Hilton-Taylor C, Stuart SN (2009) Wildlife in a changing world-an analysis of the 2008 IUCN Red List of Threatened Species. IUCN, Gland 